\title{
MANAGEMENT AND UTILIZATION OF PRODUCTIVE WAQF IN EMPOWERING COMMUNITY'S ECONOMY
}

\author{
Hardianti Yusuf \\ Lacturer at State Islamic Institute of Palopo \\ Email: hardianti.yusuf@ymail.com
}

\begin{abstract}
Productive Waqf becomesone of solution in empowering community in sector of economy. After the birth of Law no. 1 of 2004 concerning waqf that has mandated productive management of waqf. The limited paradigm management of waqf in worship has reduced the position of waqf as Islamic philanthropy. Waqf property in form of land in Bone Regency is classified enormous in terms of quantity. However, the management is not in line with the mandate of the waqf law, since it has not excellentlyaffected the economic sector. Pesantren Al-Mubarak Sibulue District Bone Regency has made a breakthrough by developing pesentren. The function of pesantren as an educational institution and its function in the economic sector. Utilization of productive waqf in empowering community'seconomy is interesting to be studied, assumed that the productive management of waqf is rare. The research data were collected through observation, interviews and documentation. The research findings showed that the management of productive waqf atPesantren Al-Mubarakismini market and broiler farm. Pesantren, as an educational institution, has a dual function, namely to finance activities planned by the school and to facilitate community to the economyaccess. Management of productive waqf is not optimaldue to inadequate human resources. The finding of this researchmight implicate for the spirit of productive waqf empowerment by providing adequate human resources as a step in maximizing the management and utilization of waqf.
\end{abstract}

Wakaf produktif menjadi salah satu solusi dalam pemberdayaan umat dalam bidang ekonomi. Pasca lahirnya UU No. 1 Tahun 2004 tentang wakaf telah mengemanatkan pengelolaan wakaf secara produktif. Paradigma pengelolaan wakaf yang terbatas dibidang ibadah telah mengurangi kedudukan wakaf sebagai filantrofi Islam. Harta benda wakaf berupa tanah di Kabupaten Bone tergolong besar dalam aspek kuantitas. Namun pengelolaanya belum sejalan dengan amanah UU wakaf, karena belum maksimal menyetuh bidang ekonomi. Pesantren Al-Mubarak Kecamatan Sibulue Kabupaten Bone telah melakukan terobosan dengan mengembangkan pesentren. Fungsi pesantren sebagai lembaga pendidikan dan fungsi pesantren dalam bidang ekonomi. Pemanfaatan wakaf produktif dalam pemberdayaan ekonomi masyarakat menjadi menarik untuk ditelaah, mengingat pengelolaan wakaf secara produktif tergolong langkah. Data penelitian 
dikumpulkan melalui observasi, wawancara dan dokumentasi. Temuan penelitian menunjukkan pengelolaan wakaf produktif di Pesantren Al-Mubarak berupa mini market dan peternakan ayam. Pesantren sebagai lembaga pendidikan, memiliki fungsi ganda yakni membiayai kegiatan-kegiatan yang direncanakan sekolah dan memberikan kemudahan masyarakat dalam akses ekonomi. Pengelolaan wakaf produktif belum maksimal (masih sederhana) disebabkan SDM yang belum mamadai. Temuan ini dapat berimplikasi pada semangat pemberdayaan wakaf secara produktif dengan meyediakan SDM memadai sebagai langkah dalam memaksimalkan pengelolaan dan pemanfaatan wakaf.

Keywords: Management; Utilization; Productive Waqf; Al-Mubarak.

\section{INTRODUCTION}

Waqf is a maliyahworship of Islamic teachings which has great value. It is stated in the hadith narrated by Muslims from Abu Hurairah that all the merits of someone will stop at the time of death, except for three things: the shadaqah jariyah, useful knowledge and shaleh children who always pray for his parents. ${ }^{1}$

Shariqah jariyah is a practice that brings endless reward to the end, even if the practitioner has passed away. Waqf is forms of jariyahdeedrecommended by religion.. ${ }^{2}$ Although the deed in the hadith does not specifically mention waqf, it does include the waqf deed. ${ }^{3}$ Waqf is one of the means to be used as a channel for the sustenance usage. ${ }^{4}$ Appreciationfor the one who do waqf is to encourage Muslims to do waqf. In the time of the Messenger of Allah, until now, waqf has been used as a medium for the use of his property.

Waqf is divided into direct ${ }^{5}$ and productive ${ }^{6}$. Discussiongrelated on the meaning of productive waqf property, it can be said that every waqf can be considered productive, which means that it produces benefits. Although it has been

${ }^{1}$ Al-Muslim, Sahih Muslim (Beirut: Dar al-Fikr, 1983) Jus III, Number Hadis 1255.

${ }^{2}$ Waqf is a gift which is carried out by keeping the main source (tahbisul ashli), then make its benefit for public. Tahbisul ashli is keeping the waqf property for not being bequeath, sold, given, rented, and etc. Whereas, the utilization is according to wakif's intention. See. Departemen Agama RI, Paradigma Wakaf Baru di Indonsia (Jakarta: Direktorat Pemberdayaan Wakaf, 2007), p. 1.

${ }^{3}$ Miftahul Huda, Mengalirkan Manfaat Wakaf Potret Perkembangan Hukum dan Tata Kelola Wakaf di Indonesia (Bekasi: Gramata Publishing, 2005), p. 32.

${ }^{4}$ Muhammad Daud Ali, Sistem Ekonomi Islam Zakat Dan Wakaf (Cet. I; Jakarta: Universitas Indonesia Press, 1988), p. 77.

${ }^{5}$ The Direct Waqf is waqf which main property is used to its objective, for instance mosque to worship, school for teaching and learning, hospital to cure patient, and etc.See. Mundzir Qahaf, Manajemen Wakaf Produktif(Cet. I; Jakarta: Khalifa, 2004), p. 162.

${ }^{6}$ Suparman Usman, HukumPerwakafandiIndonesia (Cet. I; Serang: Darul Ulul Press, 1994), p. 26. See Ibnu Katsir (Tafsir Ibnu Katsir), Sayyid Sabiq(Fiqhi Sunnah Jilid III) and Sulaiman Rasyid (Fiqhi Islam). 
known since the beginning of Umar ra, who waqf a garden in Khaibar. However, the waqf is used more often for economic purposes and does not develop.

Overriding the possibility waqf of productive things, the developingproduct that has to be developed since the value of productive waqf is great for the efforts to improve thecommunity'sprosperity. The problems that often arises in the waqf is the management and utilization.

Productive management of waqf is in the mandate of Law No. 41 of 2004 about waqf, where the provisions of waqf are not solely for the purpose of religious and social purposes but are also directed at establishing public prosperity by enhancing the economic potential and benefits of waqf. This enables the management of waqf to enter into the area of economic activity in a broad sense throughout the management in accordance with the principles of management and the syariah economy. Managing waqf objects is demanded optimally in enhancing the economic prosperity of the community.

Waqf has a strong legality with the birth of the waqf law. It is one of Islamic philanthropy ${ }^{7}$ to support the social justice agenda especially among the Muslim community. Nevertheless, the effectiveness of waqf has not been able to lift the economic level of the community. The potential for waqf is enormous, it should be managed productively and professionally to enhance the prosperity of the community. Unfortunately, the potential has not been fully developed. ${ }^{8}$

Therefore, it is important to study, analyze and apply management strategies in the framework of sustainable development of waqf so it will be useful in strengthening the economy of the community. However in order to optimize the function of the waqf and its development, it is necessary to follow the legal aspects of the waqf as practiced in Islamic history. ${ }^{9}$

In Bone Regency, as a potential area for people who waqfwhich seen from its total number of 977 waqf locations, with $750,379 \mathrm{~m}^{2}$ spread over 27 Districts. A total of 449 have certified and 528 not yet certified. ${ }^{10}$ However, most of the waqf are used for ritual aspects only, according to data by the Ministry of Religion, approximately $95 \%$ for mosque development without any productive activity in it.

The management of productive waqf is still relatively small. In Bone Regency, most of the waqf is still managed consumptively as a means of worship,

${ }^{7}$ Philantrophy means love to each other. See. Departemen Pendidikan Nasional, Kamus Besar Bahasa Indonesia. Ed. IV (Cet.I; Jakarta: PT. Gramedia Pustaka Utama, 2008), p. 391.

${ }^{8}$ Taufik Hamami, "Perwakafan Tanah dalam Politik Hukum Agraria Nasional," dalam Mukhtar Lutfi, Pemberdayaan Wakaf Produktif : Konsep, Kebijakan, dan Implementasi (Cet.I; Makassar: Alauddin University Press, 2012), p. 38

${ }^{9}$ Syamsul Anwar, StudiHukum Islam Kontemporer (Cet.I; Jakarta: RM Books, 2007), p. 76.

${ }^{10}$ The data from Ministry of Religion Bone Regency sub Head of Bimas Islam. 
schools, graves, fields, and waqf houses. Specifically focused onPesantren AlMubarak and its role in the management and utilization of productive waqf which can serve as an example and model for efforts to develop productive waqf that able and will increase independence of Pesantren. Productive waqf at Al-Mubarak Pesantren are mini markets that have been establish since 2011 and broiler farms since 2012. ${ }^{11}$

\section{DISCUSSION}

\section{A. Management of Productive Waqf}

Productive waqf management is still minor in Bone District. Most of the waqf are still managed consumptively which are used as a means of worship, schools, cemeteries, rice fields, and waqf houses. One of the locations for waqf which is still productive in Bone Regency is at the Pesantren Al-Mubarak in Sibulue Sub-District Bone Regency. Type of productive waqf found at the Pesantren AlMubarak is mini market.

The number of waqf in Bone Regency is quite large, from data obtained from the Ministry of Religion of Bone Regency as many as 449 locations with an area of 366,612 . The details of waqf in Bone Regency is in the following table.

Table 1.1.

TypesWaqf in Bone Regency

\begin{tabular}{llll}
\hline No & TypesWaqf & Location & Area $\left(\mathrm{m}^{2}\right)$ \\
\hline 1 & Mosque & 421 & 298.226 \\
\hline 2 & School & 23 & 58.058 \\
\hline 3 & Graves & 2 & 2.986 \\
\hline 4 & Rice fields & 2 & 6.834 \\
\hline 5 & House & 1 & 508 \\
\hline & Total & 449 & 366.612 \\
\hline
\end{tabular}

In general, the amount of waqf land is quite large with various types of designation. Specifically the productive waqf at Pesantren Al-Mubarak which are the focus of research which has contributed in material aspects, that are expected to sustain the independence of Pesantren in the educational and social systems. The role of the Al-Mubarak Pesantren in the management and use of productive waqf can be used as a reference and model for efforts to develop productive waqf that can foster the independence of Pesantren.

${ }^{11}$ Abd. Halid, Head of Pesantren Al-Mubarak, Interview with researcher on 20 April 2016 atHouse, Watampone. 
Productive waqf management has four underlying principles, they are principle of permanence benefits, accountability, professional management and social justice. In its development, the construction of broiler farm facilities and infrastructure has been enabled by conducting broiler breeding. The operation of broiler farms is now running.

Productive Waqf atPesantren Al-Mubarak consists of two business namely mini market and a broiler farm. It was established with high expectations that there must be a productive activity to support Pesantren and provide economic development to the communities around it. ${ }^{12}$

Both productive waqfare managed by nadzir. The technical management of businesses atPesantren Al-Mubarak depends on the specifications of the business. The flow of business management systems can be seen in the framework of the chart below.

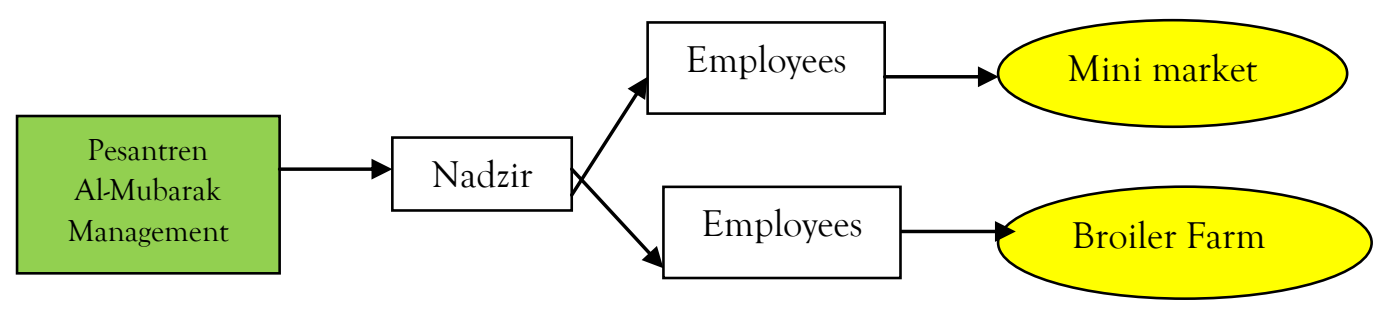

Nadzir was formed by Pesantren Al-Mubarak. Nadzir was given the authority to manage employees in each type of business (mini market and broiler farm). The employee is responsible for each business which is handled in accordance with their duties and functions. Business development will be reported by each employee to Nazir, and then forwarded to the head of Pesantren Al-Mubarak.

A manager, in this case is nadzir may be given a salary, as stated in Law Number 41 of 2004 that "in carrying out their duties, Naszir can receive a reward from the net proceeds of the management and development of waqf property thatdoes not exceed 10\%". ${ }^{13}$ However, all the managers (nadzir) atPesantren AlMubarak work because of Allah without expecting any salary or compensation, all the profits are handed over for the benefit of the pesantren. A manager (nadzir), Syamsinar explains that "regarding salaries or profits derived from mini markets or broiler farms, nothing was taken at all. All the profits are for pesantren and the community". ${ }^{14}$

\footnotetext{
${ }^{12}$ Asdin Nurdin, Nazhir (Secretary), Interview with researcher on 16 September 2016 atHouse.

${ }^{13}$ Himpunan Peraturan Perundang-Undangan Tentang Wakaf, p. 7

${ }^{14}$ Syamsinar, Bendahara Nazhir,Interview with researcher on 8 Agustus 2016 at Pondok Pesantren Al-Mubarak,Sibulue Subdistrict.
} 
Workers in the mini market are the teachers at Pesantren Al-Mubarak. They take turns working at the mini market, while in the broiler farms the wakif work as technicians, but still under the supervision of nadzir and the community. Although the benefits of productive waqf have not yet a direct impact on community, at least Pesantren can provide direct examples of productive waqf development whichis difficult to be found in the Bone Regency.

Management of productive waqf at Pesantren Al-Mubarak has sought to make waqf as Islamic philanthropy. The results of the waqf management are intended for the needs of pesantren. Waqf management by utilizing the Pesantren's human resources to minimize business management costs. It shows that the waqf management system has been categorized as productive management by empowering the existing potentials.

\section{B. Utilization of Productive Waqf in EmpoweringCommunity's Economy}

Waqf besides as ubudiyah is also has social functionwith high solidarity emotions among humans. Therefore, utilization of waqf is creating and maintaining relationship with Allah SWT. It is hablun min Allah and relation among humans as hablun min an-nas. The bigger benefits from waqf is expected to be provision for the wakif in afterlife. The good deeds of wakif will continuously flow as long as the property is utilized. The benefit of waqf empowerment besides as an effort of muslim's character building and personality which willingly give his property for other people. It is also for saving which have continuous value. The target of empowering waqf is for average community's prosperity. Waqf which managed productively is potential in constructing and empowering community's economy. ${ }^{15}$

The waqf that are carried out at Pesantren Al-Mubarak includes inwaqf khairi. This is because the results of the productive waqf are managed entirely and used to revive educational institutions. Utilization results of productive waqf is used to finance the activities of Pesantren and the needs of students which funded by foundation from managing the waqf productively. Besides, it can also be used for the wider community. Abd. Khalid as the manager (nadzir) of waqf at Pesantren AlMubarak explained that "as a Pesantren, the target must be double functioning, access to Islamic boarding schools where being able to finance the activities of Pesantren and access to the community. ${ }^{16}$ The categorization of productive waqf

\footnotetext{
${ }^{15}$ Fawait Syaiful Rahman, Manajemen Wakaf Produktif dan Kontribusinya Terhadap Penguatan Pondasi Ekonomi Masyarakat, Tafáqquh: Jurnal Penelitian dan Kajian Keislaman Vol. 7, No. 2 (2019), p. 30.

${ }^{16}$ Asdin Nurdin, Nazhir (Secretary), Interview with researcher on 16 September 2016 atHouse.
} 
management with function dualism. The priority scale of waqf is certainly for internal Pesantren Al-Mubarak.

The results of waqf management at Pesantren Al-Mubarak are categorized into two components, they are internal and external utilization. The use of waqf is done as an effort to maximize the allotment of waqf. In the concept of managing, the use of waqf must pay attention to the priority scale or become the main things needed in Pesantren.

\section{Internal Utilization}

Internal Utilization is the use intended in the pesantren itself and the results are felt by the pesantren internally. Categories in internal use are utilization for the operational costs of pesantren, for instance the majelis taklim, teaching of teacher and activities not funded by school funds or School Operational Costs (BOS). Then each activity costs is carried out by charging to pesantren from the profits of thewaqf management. So, the students are not charged on activity costs because they have been covered by the profits of pesantren businesses.

\section{External use}

External utilization is the benefit felt by the community around Pesantren Al-Mubarak. The benefits of productive waqf are not only felt by the pesantren but also indirectly have an impact on community. The utilization is packaged into various programs that can support education and for the benefit of the community. (a). Scholarship

Scholarships are given to students who consider poor by the pesantren. Nevertheless, the scholarship is not cash but in the form of goods. As based on pesantren's experience, many parents use the scholarship cash for daily needs, for example buying rice or eggs to fulfill their daily needs. They do not use it for their children's school needs. Therefore, the pesantren took the initiative to observe students' needs to be filled using productive waqf funds. ${ }^{17}$

According to students at Pesantren Al-Mubarak, the scholarship is given once a year after the semester where they can use when entering the new school year. ${ }^{18}$ The goods are in the form of stationery, bags or shoes. Giving goods is considered effective by the pesantren because these items can be directly used by students and assessed directly on target. So, students directly meet their school needs without burdening their parents. Regarding the requirements for obtaining the scholarship, the pesantren does not specify special requirements but preferably those who are less capable on the economically.

${ }^{17}$ Abd. Halid, Direktur Pondok Pesantren Al-Mubarak, Interview with researcher on 8 August 2016 at Pesantren Al-Mubarak, Sibulue Subdistrict.

${ }^{18}$ Dewi, Student, Interview with researcher on 10 August 2016 at Pesantren Al-Mubarak, Sibulue Subdistrict. 
(b) Daily necessities.

Indirectly productive waqf in the form of a mini market and broiler farms that stand at Pesantren Al-Mubarak can help the community in fulfilling their daily needs. Community's access to get out of the village is difficult, it was used as an opportunity for the Pesantren Al-Mubarak to establish a mini market. The purpose of the mini market is to make easy for students to purchase their daily needs. Communities around the pesantren also use it as a place to shop for their daily needs. Thus,thecommunity around the pesantren do not have to go outside the village to buy their daily needs.

(c) Providing loan facilities

Data obtained from the Sibulue Sub-district Office stated that most of the community's livelihoods were farmers. It means their produce is very dependent on the harvest. ${ }^{19}$ Therefore, the parties are willing to provide loans for the community. For farmers who need goods but lack financially. The pesantren are willing to lend first, after the harvest, then they pay it.

(d) Organic Fertilizer

The benefits of broiler manure as organic fertilizer are no longer a public secret. Broiler manure can be used as organic fertilizer for farming. This is utilized by the community by obtaining organic fertilizer from broiler farms which is given free of charge to the farming community that used for their land.

3. Target Group on Productive Waqf at Pesantren Al-Mubarak

The target group is a group of community who are targeted for productive waqf. Community who can enjoy the benefits of productive waqf have been agreed. The target group for productive waqf at Al-Mubarak Pesantren is for students and the community around the pesantren. The function of waqf is not only focused on students as part of pesantren, but is intended to facilitate and serve the needs of the community.

(a) Students

Supportgiven to students in form of scholarships. It is for who are underprivileged. The average students at Pesantren Al-Mubarak is classified as underprivileged and some are classified as poor. Considering the students' parents only earn a living as farmers and rely on agriculture crops. Scholarships are still limited to Madrasah Tsanawiyah (Junior High School) and Madrasah Aliyah (Senior High School). So far, they have not covered Madrasah Ibtidaiyah (Elemntary School) and Madrasah Diniyah(Kindergarten). The scholarships are given in someperiods to students.

\footnotetext{
${ }^{19}$ Documentfrom Sibulue Subdistrict Office, Bone Regency.
} 
(b) Community

In addition, the community around the productive waqf location is also the target group or target productive waqf allocation. Although, the results of productive waqf have not directly touched the community's economy. However, it is hoped that these benefits can be felt continuously by the community.

\section{Obstacles Factors of Management and Utilization of Productive Waqf in Empowering Community's Economy}

Waqf has an important role as an instrument in empowering the economy of community. In history, waqf has played an important part in the social, economic and cultural development of the community. The most prominent aspects of waqf institutions are their part in financing various Islamic and health education. Continuity of the benefits of waqf is possible by the enactment of productive waqf established to support various social, religious and academic activities.

The main role of waqf management is on nadzir individually or institutionally. Productive waqf management in Indonesia has been supported by the government in Law. No.41 of 2004 concerning waqf management through Syariah Financial Institution. Although, the law concerning productive waqf management has been implemented by the government, however some waqf institutions still manage the waqf traditionally. ${ }^{20}$

However, in its implementation, the management and utilization of productive waqf has not been maximized, so the productive waqf that expected to improve the welfare of the community cannot be carried out optimally. In Bone Regencygenerally and atPesantren Al-Mubarak in particular, the productive waqfis tend not to develop. According to the observations of researcher, it because of several factors.

1. Community's understanding of productive waqf

In general, people waqf their land in the form of immovable objects, due to their narrow understanding of the waqf. So that, the results of waqf still do not touch the community. Lack of understanding of waqf, has caused the community passive in managing waqf as a means for the welfare of the community. The Head of the Bimas Ministry of Religion in Bone, Taufik Raden said "the development of waqf in Bone Regency in general is still non-productive, it is due to the community's understanding of waqf is still dominated for of worship only". ${ }^{21}$

\footnotetext{
${ }^{20}$ Anisa Fitria Utami, Strategi Pengembangan Wakaf Produktif untuk Kesejahteraan Umat. Islamiconomic: Jurnal Ekonomi Islam, Vol. 10, No. 2, (2019).

${ }^{21}$ Taufik Raden, Kepala Seksi Bimas Islam, Interview with researcher on 29 September atMinistry of Religion Office Bone.
} 
The narrow understanding of the community, both from the people who do waqf and community in general are still on the traditional understanding. They assume waqf is only able to produce a reward of shadaqah jariyah without being accompanied by an increase in the community's economy. Ham. Isra M, one of the heads of the religious affairs office said that "the mindset of the community who thinks that the designation of waqf land must be in accordance with its intentions, so it effects on the intention of waqf. Therefore, waqf property which has the potential value to be developed economically is not managed well because it is not in accordance with the mandate of the wakif".22

This condition is caused by the patterns and systems used so far which are still traditionally and monotonous. The general community's mind has formed an image that waqf is only intended in non-economic areas. Whereas the waqf property may be empowered by developing the property, even though the type of waqf is for worship. For example by building a mini market or cooperative around the mosque. The mosque which has several floors, it can be used for the benefit of the community. Such as by renting out certain activities without reducing its essence as a place of worship.

\section{Professionalism nadzir}

The role of nadzir is needed in the management and development of productive waqf. Nadzir has a big responsibility in developing and distributing the profits of waqf. In addition, for the sake of the sustainability of waqf, nadzir has an obligation to maintain and sustain waqf. So, nadzir must be proactive and have adequate abilities, so it is not surprising that waqf sometimes does not provide benefits due to inadequate nadzir.

Community leaders, religious leaders, islamic clerics and religious teachers are sometimes trusted by the community to manage serve as nadzir. Family relationships sometimes make a person become nadzir. In reality, these nadzirs do not have managerial skills in the management and development of land or buildings to be productive.

The belief has become a tradition in the community that waqf are left to community leaders or others. While the community who are given the mandate to manage thewaqf do not have adequate abilities. That is one of the big obstacles in order to empower waqf productively.Community's understanding of the utilization waqf is still classis. Previous study explains the problems of waqf empowerment including; First, the community still understands the designation of waqf only for mosques, schools, and funerals; second, changing the designation of waqf is only

${ }^{22}$ Ham Isra M, Head of Religious Affairs of Tellusiattinge, Interview with researcher, Tellu Saittinge 1 Agustus 2016. 
limited to the wakif's message, so it cannot be developed to the potential of waqf property, this condition causes many waqf land not managed well due to Nazhir's limited action its designation. ${ }^{23}$

A teaching that has dimension ofilahiyahand insaniyah, the waqf must be accounted for in both the world and the hereafter. Responsibility to Allah SWT, personally, and institutions which have given authority and responsibility to manage waqf productively. As a suggestion to community which given the task to manage waqf, to have systematic management and accounting. This for supervision of activities and finances can be carried out effectively and accurately.

As a community institution that managing waqf. The nadzir must require of management skill in carrying out their duties. In waqf, management is needed as an effort to make waqf management activities can run effectively and efficiently. Nazhir's professionalism is a main obstacle in the waqf management. Nahzir is recruited without considering their educational background and experience. Nazhir's limitations to utilize the potential waqf is not improved, it is due to the lack of Nazir's ideas and mindset. Nazhir's skills and expertise are limited by the will of the wakif. Whereas, it is clear in the BWI rules and Law where it provides the opportunity for Nazhir to transfer the potential use of waqf property. ${ }^{24}$

The observations show that, the management function which supports in the management of productive waqf has not been carried out properly. According to the researchers, the main factor that causes the slow development of productive waqf atPesanten Al-Mubarak due to management functions that are not running well.

\section{(a) Planning}

Think about what to do with the resources. The nadzir atPesantren AlMubarak should be able to maximize the management of productive waqf they have. Productive Waqf can develop and be more beneficial for the welfare of pesantren in particular and the community in general, if they have an organized and structured plan. Including strategic plan of waqf information resources which a strategid plan as a strategy set information. Strategic plan of information resources as a collection of organizational strategy. Strategic plan of information resources by modeling and designing application of management system of waqf assets (ewaqf). Those mechanisms should be exist in managing the continuous waqf. ${ }^{25}$

\footnotetext{
${ }^{23}$ Hamzah, "Problematika Pengoptimalan Potensi Wakaf Produktif di Kabupaten Bone," Ekspose: Jurnal Penelitian Hukum Dan Pendidikan 18, No. 1 (2019), p. 746.

${ }^{24}$ Hamzah, "Problematika Pengoptimalan Potensi Wakaf Produktif di Kabupaten Bone," , p. 747.

${ }^{25}$ Amiq Fahmi and Edi Sugiarto, Sistem Informasi Geografis Untuk Pengelolaan Dan Monitoring Persebaran Aset Wakaf. Techno. Com, Vol. 15, No. 4, (2016), p. 327-334.
} 


\section{(b) Organizing}

Based on the facts in the site, the researcher found that the organization structure of nadzir was not well organized. Duties and responsibilities that should be for each member, are not carried out properly. That result is in less optimal management of waqf at Pesantren Al-Mubarak.

(c) Implementation

Implementation is carried out when there are plans to be implemented. In fact, the nadzirs atPesantren Al-Mubarak have no plans to develop productive waqf to the maximum. Because of the lack of adequate funds and human resources to manage waqf are the cause of non maximized in productive waqf management.

(d) Controlling and Supervising

The process is carried out to ensure the entire set of activities that have been planned, organized, and implemented in accordance with the expected targets even if changes occur. In managing productive waqf atPesantren Al-Mubarak, its control and supervision are not given enough attention. There is no evaluation in productive waqf management so it is not known whether nadzir in carrying out his duties was successful or not.

(e) Reporting

Reporting is a mechanism and process of providing information and explanation accompanied by various kinds of evidence regarding a particular type of business. Reporting is carried out by business actors to the business parties. In the context of productive waqf empowerment, reporting of productive waqf empowerment assistance is carried out by Nadzir to the Director General of Islamic Community Guidance, Ministry of Religion of the Republic of Indonesia. ${ }^{26}$

According to the Regulation of the Director General of Islamic Community Guidance Number Dj. II / 503 of 2007 concerning the management of productive waqf empowerment assistance, it is stated that reporting is as nadzir accountability regarding the productive waqf empowerment assistance is carried out in three ways: first, nadzir submits a report on the utilization of assistance regularly every 3 (three) months, by submitting evidence expenditure of funds to the Director General. Second, nadzir submits a report on the benefits of empowering the director general every 6 (six) months both in managing goods and services allocated for the benefit of service. Third, after the achievement of Break Even Point (BEP), nadzir must report to the Director General.

\footnotetext{
${ }^{26}$ Kementerian Agama RI, Pedoman Penyusunan Proposal Pemberdayaan Wakaf Produktif (Jakarta:Direktorat Jenderal Bimbingan Masyarakat Islam, 2012), p. 51
} 
In addition, reporting can also be deemed necessary and important to be conveyed to the community to emphasize more on the responsibility side of the empowerment of productive waqf around them. The report can be submitted verbally in various community forums, such as village meetings / meetings or also other forums that are deemed appropriate and appropriate.

The report was not carried out by nadzir at Pesantren Al-Mubarak. According to the researcher this causes the non-development of waqf atPesantren Al-Mubarak. Whereas the pesantren has received a reprimand from the Ministry of Religion because the funds to build productive waqfare productive waqf empowerment funds that must have an accountability reports.

\section{Lack of Government Role}

The government has an important role in a country, including the management of waqf. Ibnu Nujaim expressed that the policies of a government must be based on the principle of benefit. All matters relating to the public importance,then each policy can be implemented if it is in line with the principle of benefit. However, if it is considered contrary to the principle of benefit, it should not be implemented. ${ }^{27}$ The issue of waqf is a product of Islamic law, waqf as a source of Islamic finance that can be managed for community's prosperity. Therefore, issuing rules relating to optimizing waqf is a benefit, because it is highly recommended by religion to help each other in kindness. Waqf has been practiced during the time of the Messenger of Allah and Sabahat Umar ra. who has done waqf the land in Khaibar.

Trainings conducted by the Government for nadzir and lack of supervision of waqf in Bone Regency is relatively undeveloped. As stated from one of the nadzir in Pesanten, he has never participated in training to develop his understanding of the duties and functions of Nazir. In addition, strengthening in the economic field as a provision in developing waqf has never been held by the Ministry of Religion. ${ }^{28}$ As a result of inadequate understanding of Nadzir, the absence of government efforts in anticipating the obstacles faced by Nadzir is the cause of the non-optimistic management of productive waqf atPesantren Al-Mubarak. There are various efforts have been made to minimize the various activities carried out.

(a). Socialization to the Community

Conducting socialization about productive waqf to the community is to change the paradigm of society about productive waqf.Thewaqf are not only for worship and education but can be directed to productive things. Though the

\footnotetext{
${ }^{27}$ Lukman Arake, Otoritas Kepala Negara dalam Menentukan Suatu Kebijakan Perspektif Siyasah Syar'iyah. Al-Bayyinah, Vol. 3 No. 2 (2019), p. 176.

${ }^{28}$ Asdin Nurdin, Nazhir (Secretary), Interview with researcher 16 September 2016
} 
potential for waqf is greater than zakat if it can be managed properly. This is being done by the Ministry of Religion Bone to the local mosques and KUA. Socialization carried out only come to a conclusion, but the application is not relevant.

(b). Legislation

The birth of Law No.41 of 2004 is a starting point to increase the potential empowerment of waqf in Indonesia to a productive direction. The waqf law has become a force in the management of waqf, the law has stated that the waqf institution is a religious institution that has the potential and economic benefits that need to be managed efficiently for public prosperity. ${ }^{29}$

The intended empowerment contains a comprehensive understanding with a broad dimension. The waqf includesmoveable and immovable property which managed by Nazir in development properties of waqf institutions. Their distribution is not limited to the establishment of worship place and socio-religious only. In summary, the regulation is sufficient in productive waqf management, but the execution in optimizing the mandate of the law has not been seen significantly.

(c). The formation of the Nazhir Forum

Nadzir as the frontmen of managing and developing waqf property. They are given motivation and guidance in order to improve management professionalism through various training and orientation. In this case, the quality of nadzir continues to be improved by providing direction and motivation to reform manjaerial and individual skills. These are crucial in the productive waqf empowerment.

Therefore, the Ministry of Religion formed the Nadzir Forum in 2016 which is chaired directly by the Islamic Community Guidance Committee. The duties and obligations of Nadzir forums are (a) organizing guidance regarding the duties and obligations of Nadzir; (b) discussing and formulating the issue waqf landutilization; (c) accommodating the aspirations of community regarding the management of waqf land; (d) providing input or ideas regarding the management of waqf land; (e) helping the settlement of waqf land management issues. ${ }^{30}$ Nevertheless, these activities have not been fully carried out by the ministry in reality. As the consequence, nadzir still considers himself to be the only player in the management of waqf.

${ }^{29}$ Dharma Satyawan and Achmad Firdaus, Bayu Taufiq Possumah, Analisis Strategi Pengelolaan Wakaf Produktif di Indonesia, Al-Kalam Jurnal Komunikasi, Bisnis dan Manajemen, Vol. 5, No. 2, (2019), p. 49-64.

${ }^{30}$ Letter of Decree Head of Ministry of Religion Bone Regency. Number 589 of 2016, Concerning Formation of Nazhir Forum in Bone Regency, 2016-2019 periods. 


\section{CONCLUSION}

Management of productive waqf at Pesantren Al-Mubarak in the form of a mini market and broiler farm established with the help of funds from the government through productive waqf empowerment funds. Utilization of productive waqf in community's economic empowerment atPesantren Al-Mubarak has not been maximized. As an educational institution, the goals are to provide benefits internally and externally, but it is still in a medium scale (simple). So, it has not been able to have a major impact on society.

Obstacles on management and productive waqf utilization in Bone Regency atPesantren Al-Mubarak, are caused by a lack of public understanding of productive waqf, weakprofessionalism ofnadzir, and lack of government attention to the development of waqf institutions. Socialization on productive waqf, waqf regulations, and the formation of Nazir forum. All of these has been attempted, but in its application it has not been able to make a major contribution to community. The limitation of human resources of waqf management is alsoa major obstacle and understanding the empowerment of waqf is inadequate as well. So,the management and utilization of productive waqf is still relatively simple.

\section{REFERENCES}

Ali, Mohammad Daud, Sistem Ekonomi Islam: Zakat dan Wakaf. Depok:UI press, 1988.

Anwar Syamsul. StudiHukum Islam Kontemporer. Cet.1; Jakarta: RM Books, 2007.

Arake, Lukman. Otoritas Kepala Negara dalam Menentukan Suatu Kebijakan Perspektif Siyasah Syar'iyah. Al-Bayyinah, Vol. 3 No. 2 (2019).

Fahmi, Amiq and Edi Sugiarto, Sistem Informasi Geografis Untuk Pengelolaan Dan Monitoring Persebaran Aset Wakaf. Techno. Com, Vol. 15, No. 4, (2016).

Fawait Syaiful Rahman, Manajemen Wakaf Produktif dan Kontribusinya Terhadap Penguatan Pondasi Ekonomi Masyarakat, Tafáqquh: Jurnal Penelitian dan Kajian Keislaman Vol. 7, No. 2 (2019), h. 30.

Departemen Agama RI, Paradigma Wakaf Baru di Indonsia. Jakarta: Direktorat Pemberdayaan Wakaf, 2007.

Departemen Pendidikan Nasional, Kamus Besar Bahasa Indonesia. Ed. IV. Cet.I; Jakarta: PT. Gramedia Pustaka Utama, 2008. 
Hamami, Taufik. "Perwakafan Tanah dalam Politik Hukum Agraria Nasional," dalam Mukhtar Lutfi, Pemberdayaan Wakaf Produktif: Konsep, Kebijakan, dan Implementasi. Cet.I; Makassar: Alauddin University Press, 2012.

Hamzah, H. (2019). Problematika Pengoptimalan Potensi Wakaf Produktif di Kabupaten Bone. Ekspose: Jurnal Penelitian Hukum dan Pendidikan, 18(1), $741-752$.

Huda,Miftahul. Mengalirkan Manfaat Wakaf Potret Perkembangan Hukum dan Tata Kelola Wakaf di Indonesia.Bekasi: Gramata Publishing, 2005.

Kementerian Agama RI, Himpunan Peraturan Perundang-Undangan Tentang Wakaf, Direktorat Jenderal Bimbingan Masyarakat Islam, 2012.

Kementerian Agama RI, Pedoman Penyusunan Proposal Pemberdayaan Wakaf Produktif. Jakarta:Direktorat Jenderal Bimbingan Masyarakat Islam, 2012.

Lubis,Suhrawardi K. Wakaf dan Pemberdayaan Umat. Cet. II; Jakarta: Sinar Grafika, 2010.

Mundzir Qahaf, Manajemen Wakaf Produktif. Cet. I; Jakarta: Khalifa, 2004.

al-Muslim, Sahih Muslim. Beirut: Dar al-Fikr, 1983. Juz III, Nomor Hadis 1255

Usman, Suparman. HukumPerwakafandiIndonesia . Cet. I; Serang: Darul Ulul Press, 1994. Lihat Juga Ibnu Katsir (Tafsir Ibnu Katsir), Sayyid Sabiq (Fiqhi Sunnah Jilid III) and Sulaiman Rasyid (Fiqhi Islam).

Utami, Anisa Fitria. Strategi Pengembangan Wakaf Produktif untuk Kesejahteraan Umat. Islamiconomic: Jurnal Ekonomi Islam, Vol. 10, No. 2, (2019).

Rahman, Fawait Syaiful. Manajemen Wakaf Produktif dan Kontribusinya Terhadap Penguatan Pondasi Ekonomi Masyarakat, Tafáqquh: Jurnal Penelitian dan Kajian Keislaman Vol. 7, No. 2 (2019).

Satyawan, Dharma and Achmad Firdaus, Bayu Taufiq Possumah, Analisis Strategi Pengelolaan Wakaf Produktif di Indonesia, Al-Kalam Jurnal Komunikasi, Bisnis dan Manajemen, Vol. 5, No. 2, (2019). 